fact that the jet does not strike the edge centrally. If the velocity is increased very slowly, however, the fundamental is elicited first at $e$. This presumably is due to the fact that the fundamental frequency, $n=130 \mathrm{c} / \mathrm{sec}$., is less than half the octave, $n=264 \mathrm{c} / \mathrm{sec}$., so that the edge tone reaches double the fundamental of the pipe before reaching equality with the octave. When the octave sounds at $f$, the pipe takes complete control and the frequency remains constant (Stage II). When the velocity reaches $550 \mathrm{~cm} . / \mathrm{sec}$. at $h$, the real fundamental of the pipe begins to sound and the jet oscillates as a whole from side to side
(Stage I). The octave note can still be heard but disappears at $i$. The occurrence of Stage I at such a high velocity is quite impossible without a resonator.

It seems, then, that edge tones are responsible for the initiation of the vibrations in musical wind instruments of the organ type, and that even the details of the complex initial phenomena can be accounted for adequately.

\footnotetext{
1 Rayleigh, Scientiflc Papers, 2, p. 95.

'Lutz, P., Beiträge z. Anat. u. Physiol., 17, 1 (1921).

${ }^{3}$ Gunnaiya, D., and Subrahmaniam, G., Proc. Phys. Soc., 37, 15 (1924).

- Brown, G. Burniston, Proc. Phys. Soc., 49, 493 and 508 (1937).
}

\title{
Scientific Centenaries in 1938
}

\section{By Engineer Captain Edgar C. Smith, O.B.E., R.N.}

$\mathrm{T}$ HE scientific centenaries which occur this year are of wide and varied interest. They include the tercentenary of the printing at Amsterdam of Galileo's great work, the "Dialogues of the Two Sciences of Mechanics and Motion", and of the birth of the Scottish mathematician James Gregory; the bicentenary of the death of Boerhaave, the famous Dutch physician and chemist, and the bicentenary of the birth of Sir William Herschel; and the centenaries of the death of Dulong, the French chemist and physicist, and of Nathaniel Bowditch, the American mathematician and astronomer, and also the centenaries of the birth of Sir William Perkin, Ernest Solvay, Cleveland Abbe, George James Symons, Pietro Tacchini and of Count Zeppelin. The year 1738 also saw the publication of Daniel Bernoulli's "Hydrodynamics", while the year 1838 witnessed, first the inauguration of transAtlantic steam navigation, and secondly, the opening of the whole of the railway line from London to Birmingham, constructed by Robert Stephenson.

James Gregory (1638-75) was the younger brother of David Gregory (1627-1720). Together they founded the scientific fame of a family of men of science. When about twenty-four years of age, James published his "Optica Promota", containing the description of the Gregorian reflecting telescope, and suggestions for utilizing the transits of the minor planets for accurately determining the solar parallax. He studied at Padua, had a controversy with Huygens, corresponded with Newton, and in 1668 was made professor of mathematics in the University of St. Andrews, and in 1674 professor of mathematics at Edinburgh. In October 1675, while showing the satellites of Jupiter to his students, he was struck blind, and he died a few days later. An English contemporary of Gregory was Edward Bernard (1638-97), who was Wren's successor in the Savilian chair of astronomy at Oxford. He held this post from 1673 until 1691, when he was succeeded by David Gregory, the nephew of James. Bernard was a clergyman, having graduated from St. John's College, Oxford. His sole recorded astronomical observation is that of the solar eclipse of July 2,1684 , but he was an indefatigable collector of mathematical manuscripts. The year 1638 also saw the birth of the French botanist Pierre Magnol (1638-1715) of Montpellier. Both botanist and physician, he held the chair of medicine in his native town and was physician to Louis XIV. In 1705 he visited Paris and was admitted to the Academy of Sciences, but his heart was in his botanic garden at Montpellier. The genus Magnolia was named after him by his countryman Plumier.

Among the men of science, besides Boerhaave, who died in 1738, were Benedict de Maillet, the French geologist, and Richard Helsham, the Irish natural philosopher. De Maillet, who was born in 1656, came of a noble family of Lorraine. At thirty-three years of age, he was made consulgeneral in Egypt, and he held this position for fifteen years. $\mathrm{He}$ was also consul-general at Leghorn, and travelled in the Near East. He left a description of Egypt and a geological work in 
which he regarded all the rocks of the earth as marine deposits. The work was written in 1715-16, but was not published until some years after his death, when it appeared under the title "Telliamed", an anagram of de Maillet. It contains six imaginary dialogues between an Indian philosopher, Telliamed, and a French missionary. After reviewing this work, von Zittel concluded that "if we except the concluding chapters, the Telliamed far outshines other geological writings of the eighteenth century in its wealth of observed facts, its daring originality and its charm of style". Helsham, who was born about 1682, spent nearly the whole of his life in Dublin. A fellow of Trinity College, he lectured on mathematics and was the first to be appointed to the professorship of natural philosophy founded out of the funds left by the merchant Erasmus Smith. Helsham was a great friend of Dean Swift.

Hermann Boerhaave, who was born on December 21,1668 , and died on September 23, 1738, has been referred to as the most celebrated physician of the eighteenth century. He was equally at home in theology, music, botany and chemistry. He extended the botanic garden at Leyden, and in 1718 became professor of chemistry in the University. His well-known work "Elementa Chemiæ" was translated into several European languages. He was a foreign member of both the Paris Academy of Sciences and of the Royal Society. $\mathrm{He}$ is buried in St. Peter's, Leyden.

The bicentenary of the birth of Sir William Herschel, who was born on November 15, 1738, will recall the name of one of the greatest of astronomical discoverers. For fifty years his aim was to obtain "a knowledge of the construction of the heavens". In her "History of Astronomy" Miss Clerke wrote: "The rise of Herschel was the one conspicuous anomaly in the astronomical history of the eighteenth century. It proved decisive of the course of events in the nineteenth. It was unexplained by anything that had gone before; yet all that came after hinged upon it. It gave a new direction to effort; it lent a fresh impulse to thought. It opened a channel for the widespread public interest which was gathering towards astronomical subjects to flow in". The year 1738 also saw the birth of the famous French hydrographer, Charles Pierre Claret, Comte de Fleurieu (1738-1810), who had been entrusted with the testing of the marine chronometers of Berthoud, and who organized the expeditions of La Perouse and D'Entrecasteaux; the French aeronaut Jean-Pierre Blanchard (17381809), who with Dr. John Jeffries on January 7, 1785, made the first crossing of the Channel by balloon; the German mineralogist Franz Ludwig von Cancrin (1738-1816), who directed the salt mines of Russia and published a work in thirteen volumes on mining ; and also of ChristophePhilippe Oberkampf (1738-1815), who added to the wealth of France by introducing the art of calico printing. Born in Germany, his life's work was done in France, and he received a decoration of the Legion of Honour from Napoleon.

Of the men of science who died a century ago, passing mention may be made of Samuel Woodward (1790-1838), the Norwich bank clerk who published a book containing a list of all British fossils then known; Thomas Andrew Knight (1758-1838), the horticulturist whose efforts were directed to the improvement of fruit trees; Charles Tennant (1768-1838), who in 1799 patented a process for the production of bleaching powder, and in 1800 founded the great chemical works at St. Rollox, Glasgow ; Bernard Courtois (17771838), the discoverer of iodine; and Pierre-Louis Dulong (1785-1838), a professor at the Paris Ecole Polytechnique and one of the secretaries of the Paris Academy of Sciences, who with AlexisThérèse Petit (1791-1820) made important investigations in heat and chemistry. Nathaniel Bowditch, who also died in 1838, began life in a ship-chandler's shop, but rose to be president of the American Academy of Arts and Sciences. His great work was his translation, with a commentary, of Laplace's "Mécanique Céleste", which Simon Newcomb said "made an epoch in American science by bringing the great work of Laplace down to the reach of the best American students of his time". His countryman, Colonel John Stevens (1749-1838), a pioneer of steam transport, constructed the first steam boat driven by a screw propeller, and with his sons did much to further both railways and steam navigation.

The work of this last group of men belongs to the early part of the nineteenth century, just when the value of scientific studies was becoming increasingly appreciated, when technical schools were being opened and physical and chemical laboratories were being established. The seed sown in these laboratories was to bear a fruitful harvest, and no industry benefited more from their establishment than the chemical industry. A century ago, Liebig was making the Giessen laboratory the Mecea of chemical students, and Wöhler had already begun teaching at Göttingen. One of Liebig's students was Hofmann, who came to London in 1845 to teach at the old Royal College of Chemistry, in which Sir William Perkin-whose centenary occurs in March-was studying when he made the discovery which laid the foundation of the coal-tar colour industry. Perkin was only eighteen years of age when he discovered aniline 
mauve and only nineteen when he started its manufacture at Greenford Green, near Harrow. Fifty years later, he was the central figure of a great international gathering which assembled to celebrate the jubilee of his discovery. The agricultural chemist Robert Warington (1838-1907) also owed something to Hofmann. Warington worked under both Lawes and Frankland, and for many years took part in the work at Rothamsted. Other chemists born a century ago were Wladimir Markownikoff (1838-1904), whose work was of great importance to the Caucasian petroleum industry; Ernest Solvay (1838-1922) whose patent of 1863 led to a revolution in the manufacture of common soda, and François Lecog de Boisbaudran (1838-1912), who first isolated gallium and received the Davy Medal of the Royal Society.

Passing from the ranks of the chemists to those of the physicists and astronomers, two of the outstanding meteorologists of last century were George James Symons (1838-1900) and Cleveland Abbe (1838-1916). Symons was the founder of the British Rainfall Organisation and of Symons' Meteorological Magazine, now the Meteorological Magazine. He was twice president of the Royal Meteorological Society, and every two years his name is recalled by the award of the Symons Medal founded to his memory. Abbe at first was an astronomer, but from the passing by the United States Congress of the Weather Bureau Act in 1870 until his death he was the leading meteorologist in his country. Among Abbe's countrymen were James Craig Watson (1838-80), director of the Ann Arbor Observatory, who discovered twenty-two minor planets and wrote a standard text-book on theoretical astronomy, and George William Hill (1838-1914), who in 1909 was awarded the Copley Medal of the Royal Society for his researches on the theory of the moon. Hill's career was bound up with the "American Ephemeris and Nautical Almanac". Two other astronomers born at the same time were Pietro Tacchini (1838-1905), the successor of Secchi at the observatory of the College Romano and the organizer of the Meteorological and Geodynamical Institute of Rome, and Arthur Auwers (1838-1915), whose work was mainly concerned with the fundamental systems of star places and proper motion. His new "Reduction of Bradley's Observations" occupied him from 1866 until 1876. In 1912 , the fiftieth anniversary of his doctor's degree, the Berlin Academy of Sciences instituted the Bradley Medal and British astronomers presented Auwers with a copy of the portrait of Bradley by J. Richardson.

To these names may be added those of Ernst Mach (1838-1916) of Prague and Vienna, whose researches in mechanics led him to study by means of photography the motion of a bullet through air ; Karl Selim Lemström (1838-1904) of Helsingfors, who made researches on atmospheric electricity, and the effect of electricity on plants ; Carl-Louis Schwendler (1838-82), an electrical engineer of German nationality who worked many years with the telegraph department of India; and General Charles Webber (1838-1904), an officer of the Royal Engineers, who was also an expert in telegraphy and assisted the Post Office to organize its telegraph department and with Sir Francis Bolton in 1871 founded the Society of Telegraph Engineers, now the Institution of Electrical Engineers. The geologists, Sir William Boyd Dawkins, Ferdinand Stoliczka and Alfred Elis Törnebohm, were also born in 1838, as was Sir Walter Lawry Buller, the New Zealand ornithologist, to whom there is a tablet in St. Paul's Cathedral.

of the many inventors and engineers born in 1838 who in one way or another made their mark, Samson Fox (1838-1903) was the inventor of the corrugated flue for boilers which was adopted in all classes of steamships, and a pioneer of the acetylene industry; Peter Brotherhood (18381902) was a pioneer in the construction of highpressure air compressors and of high-speed steam engines; Charles Edward Emery (1838-98) did important work in marine engineering and was responsible for the construction of a central station for house-to-house distribution of steam ; Henry Spencer Palmer (1838-1893), a British military engineer, was a geodicist of note and designed the Hong Kong Observatory as well as public works in Japan; William Henry Maw (1838-1924) was president of the Institution of Civil Engineers and of the Royal Astronomical Society and for more than fifty years editor of Engineering, while William Cawthorne Unwin (1838-1933) was, in the words of Lord Balfour, "one whose name was honoured wherever engineering was studied in Englishspeaking lands". Count Zeppelin, who has already been mentioned, was born on July 8, 1838, and died on March 8, 1917, eighteen years after he had built his first airship.

Of all the achievements of engineers in 1838 the place of honour belongs to the men who promoted the plans and built the ships for trans-Atlantic steam navigation. Four steamships, the Sirius, Royal William, the Liverpool and the Great Western, made passages between England and New York in 1838 , but it was the performances of Brunel's Great Western-the Queen Mary of her day-that opened men's eyes to the possibilities of steam navigation. The centenary of her first voyage will be commemorated in various ways, and a special exhibition in connexion with the event is being arranged at the Science Museum, South Kensington. 